\title{
Managing Bahiagrass in Hybrid Bermudagrass Pastures ${ }^{1}$
}

\section{B. A. Sellers and J. A. Ferrell ${ }^{2}$ \\ Introduction}

Bahiagrass is the most common forage grown in Florida, covering approximately 2.5 million acres. The popularity of bahiagrass in Florida can be attributed to its drought tolerance, low fertility requirements, and persistence even under heavy grazing.

Although bahiagrass is an important forage species, it can be a serious weed problem for those wishing to produce high-quality bermudagrass hay. Bahiagrass typically does not invade a healthy bermudagrass sward, but as the stand begins to thin and nutrients such as nitrogen become limiting, bahiagrass invasion is common. Additionally, a small percentage of bahiagrass seed can remain in the soil for several years. A healthy bermudagrass sward is necessary to prevent bahiagrass establishment, but herbicides can be used if encroachment begins.

\section{Prevention}

Bahiagrasses do not tolerate shade. Therefore, maintaining a good bermudagrass stand is one way to prevent bahiagrass invasion. For specific recommendations concerning management practices for bermudagrass cultivars, see the EDIS publication SS-AGR-60 Bermudagrass Production in Florida. In addition to maintaining a good bermudagrass stand, prevent movement of bahiagrass seeds into a bermudagrass pasture. This can be accomplished by cleaning hay equipment and not feeding bahiagrass in a bermudagrass pasture. Bahiagrass tends to tolerate stresses such as drought and insect pressure. Therefore, be aware that bahiagrass invasion may occur when such conditions are prevalent.

\section{Chemical Control}

The Cimarron ${ }^{\circledR}$ (formerly known as Ally®) label states that established bahiagrass cultivars can be controlled with 0.3 ounces of product per acre. Cimarron must be applied after greenup, but before seedhead formation for optimum control. A surfactant, such as crop oil concentrate $(1 \% \mathrm{v} / \mathrm{v})$ or a non-ionic surfactant $(0.25 \% \mathrm{v} / \mathrm{v})$ must also be added to the tank. Additionally, spray grade ammonium sulfate ( $2 \mathrm{lb} / \mathrm{acre})$ or a liquid nitrogen ( $2 \mathrm{qt} / \mathrm{acre}$ of 28 or $32 \% \mathrm{~N}$ ) source may be added to enhance Cimarron activity under arid conditions. Cimarron activity under dry conditions tends to be lower than when

1. This document is SS-AGR-257, one of a series of the Agronomy Department, Florida Cooperative Extension Service, Institute of Food and Agricultural Sciences, University of Florida. Published September 2005. Visit the EDIS Web Site at http://edis.ifas.ufl.edu.

2. B. A. Sellers, assistant professor, Agronomy Department, Range Cattle Research and Education Center--Ona, FL; J. A. Ferrell, assistant professor, Agronomy Department; Florida Cooperative Extension Service, Institute of Food and Agricultural Sciences, University of Florida, Gainesville, FL.

The use of trade names in this publication is solely for the purpose of providing specific information. UF/IFAS does not guarantee or warranty the products named, and references to them in this publication does not signify our approval to the exclusion of other products of suitable composition. Use herbicides safely. Read and follow directions on the manufacturer's label. 
rainfall is adequate. Therefore, it is best to wait to apply Cimarron if dry conditions are present.

In the early 1990s, an application of Cimarron to a bermudagrass pasture failed to control bahiagrass contaminants. This was the first evidence that some bahiagrass cultivars may not be effectively controlled with this herbicide. Several bahiagrass cultivars are grown in Florida including: Common, Pensacola, Tifton-9, Paraguayan, and Argentine.

Therefore, experiments were conducted to determine whether the various bahiagrass cultivars differ in their sensitivity to Cimarron.

\section{Cultivar response}

University of Florida research by Baker (1996) has shown that bahiagrass cultivars differ dramatically in their response to Cimarron (Table 1). Argentine, Common, and Paraguayan cultivars had greater tolerance to Cimarron while Pensacola and Tifton-9 were the most susceptible.

Studies were also conducted on seedlings to determine if plant age affected control. It was found that tolerant cultivars, such as Paraguayan and Argentine, are tolerant to Cimarron from the very beginning. Although weeds are generally more susceptible to herbicides soon after germination, at no time will Cimarron be expected to control these tolerant cultivars. Although multiple applications may improve control of these difficult cultivars, no more than $0.4 \mathrm{oz} /$ acre per application or $12 / 3 \mathrm{oz} /$ acre per year of Cimarron may be applied.

Producers must be able to determine what bahiagrass cultivar is present prior to bermudagrass establishment. If a tolerant bahiagrass cultivar is present, it will be necessary to sufficiently control the bahiagrass prior to establishing bermudagrass. For Cimarron-tolerant bahiagrass varieties, total control could be achieved with an application of glyphosate (Roundup®, Touchdown ${ }^{\circledR}$, etc.) at $3 \mathrm{qt} /$ acre followed by additional glyphosate if complete bahiagrass control is not achieved or new bahiagrass seedlings emerge. In established stands of bermudagrass, spot-treatments of glyphosate products will be required to control Cimarron-tolerant bahiagrasses. Alternatively, a producer may wish to grow annual forages such as ryegrass during the cool season and warm season annual grasses such as pearl millet for at least one full growing season. Tillage operations prior to establishment will help deplete the bahiagrass soil seed bank.

\section{Reference}

R. D. Baker. 1996. Differential susceptibility of five bahiagrass (Paspalum notatum Fluegge) cultivars to metsulfuron methyl. Ph.D. diss. University of Florida-IFAS. 
Table 1. Control of bahiagrass cultivars 4 weeks after Cimmaron treatment.

\begin{tabular}{||c|c|c|c|c|c||}
\hline \hline Cimarron rate & Pensacola & Tifton-9 & Argentine & Common & Paraguayan \\
\hline oz/acre & \multicolumn{2}{|c|}{$------\cdot$} \\
\hline 0.3 & 81 & 90 & 49 & 60 & 56 \\
\hline 0.4 & 81 & 90 & 56 & 65 & 60 \\
\hline \hline
\end{tabular}

